\title{
BINDING OF AROMAFORMING CRYO- AND THERMOTROPIC JELLIES OF GELATIN AND STARCH
}

\author{
Nataliya Lashko1, ${ }^{*}$, Nataliya Derevianko ${ }^{2}$, Galina Dudarieva ${ }^{1}$
}

https://doi.org/10.23939/chcht11.04.480

\begin{abstract}
The regularities of binding substances of aromaforming cryo- and thermotropic jellies of gelatin and starch were studied. The influence of the surface of hydrophobic jelly on their ability to absorb aqueous solutions of thymol was experimentally confirmed. The reduction of sorption by thymol cryotropic jellies versus the thermotropic one was established. Experimentally it was confirmed that the most promising technology to create flavors from aromatic hydrophobic substances are thermotropic jellies y of gelatin with high hydrophobicity.
\end{abstract}

Keywords: thymol, gelatin, starch, hydrophobicity, hydrophilicity, angle of wetting, persorption, desorption.

\section{Introduction}

Flavors are widely used in food industry to ameliorate organoleptic quality factors and to raise consumer price of foodstuffs. Biopolymers (proteins and polysaccharides), being part of food items, can considerably influence on the composition of volatile aromatic compounds. In the result of specific interaction of biopolymers with the mentioned compounds the balance of their composition is upset.

Today it is known that the rate of odorants binding depends on the physical and chemical properties of both volatile organic compounds and an inert matrix. In a number of studies the interaction of various polysaccharides starch and corn starch cryotextures with individual organic compounds and their mixtures was investigated [1-4]. It was found that the retention of volatile starch matrix compounds is due to capillary and surface adsorption, the formation of hydrogen bonds and inclusion complexes. In addition, it was shown that odorants can form supramolecular complexes (supramolecular associates) with cryotextured poly-

\footnotetext{
${ }^{1}$ National University of Zaporozhya,

62, Gogol St., 69002 Zaporizhzhya, Ukraine

${ }^{2}$ Khortitska National Academy of Education and Rehabilitation,

59, Naukove mistechko St., Khortitsa, 69017 Zaporizhzhya, Ukraine * pechar@ua.fm

(c) Lashko N., Derevianko N., Dudarieva G., 2017
}

saccharides up to $0.3-0.5$ microns by hydrophobic cooperative interactions [5].

Hydrophobic nature of the interaction of aromatic compounds with aqua solutions is confirmed in the works [6-8]. Hydrophobic nature of the interaction of aromatic compounds with gelatin and starch is confirmed in the works $[9,10]$. Nowadays, studying the mechanism of interaction of odorant in the system - inert matrix and the search for new, effective sorbents are still an actual problem [11, 12].

In this regard, attention-grabbing food matrix as inert gelatin and starch is used in the production in a large group of food products. We hypothesized that fixing the conformation of biopolymers by creating thermal cryotropic jellies and opening new opportunities in their sorption activity besides aromatic substances with sufficiently high hydrophobicity should have affinity for hydrophobic and hydrophilic surfaces of jellies.

The purpose of this article is to examine the patterns of the binding of aroma-forming agents by hydrophobic and hydrophilic surfaces cryo- and thermotropic jellies of gelatin and starch.

\section{Experimental}

The objects of the study were: thymol, $20 \%$ gelatin, gelatin-starch and gelatin-thymol jelly. All kinds of jelly were formed under high ionic strength $-0.5 \mathrm{M}$ sodium chloride.

Preparation of thermotropic $20 \%$ gelatin jellies. Thermotropic $20 \%$ gelatin jellies were prepared by the following procedure: $20 \mathrm{~g}$ of gelatin, $80 \mathrm{ml}$ of purified water and $2.3 \mathrm{~g}$ of sodium chloride were placed into $300 \mathrm{ml}$ glass vessel and left for $20 \mathrm{~min}$. After the gelatin swelled, the vessel was put into water bath and heated at $363 \mathrm{~K}$ for $40 \mathrm{~min}$ under intensive stirring. Then melted gelatin was put into a Petri dish and cooled for $18 \mathrm{~h}$ at $278 \mathrm{~K}$.

Preparation of thermotropic starch-gelatin jellies. Thermotropic starch-gelatin jellies were prepared by the following procedure: $20 \mathrm{~g}$ of gelatin and $2.3 \mathrm{~g}$ of purified sodium chloride were placed into the $300 \mathrm{ml}$ capacity 
glass to create $0.5 \mathrm{M}$ of the liquor. The latter was soaked in $70 \mathrm{ml}$ of water for $20 \mathrm{~min}$. Then $10 \mathrm{~g}$ of starch were added and the liquor was heated at $363 \mathrm{~K}$ during $40 \mathrm{~min}$ under intensive mixing. Then it was poured into a Petri dish and cooled at $278 \mathrm{~K}$ for $18 \mathrm{~h}$.

Preparation of thermotropic gelatin-thymol jellies. Thermotropic gelatin-thymol jellies were prepared by the following procedure: $20 \mathrm{~g}$ of gelatin and $2.3 \mathrm{~g}$ of purified sodium chloride were placed into the $300 \mathrm{ml}$ capacity glass to create $0.5 \mathrm{M}$ of the liquor. The latter was soaked in $70 \mathrm{ml}$ of $0.05 \%$ aqueous solution of thymol for $20 \mathrm{~min}$. After the gelatin being swelled, the glass was put on the water bath and the liquor was heated at the temperature of $363 \mathrm{~K}$ during $40 \mathrm{~min}$ under intensive mixing. Then the melted gelatin was poured into a Petri dish and cooled at $278 \mathrm{~K}$ for $18 \mathrm{~h}$. Then the jellies were washed with $500 \mathrm{ml}$ of distilled water $(5 \times 100 \mathrm{ml})$ to remove retained thymol.

Preparation of starch and gelatin cryotexturates. Starch and gelatin cryotexturates were prepared by the following procedure: $20 \mathrm{~g}$ of gelatin were placed into the $300 \mathrm{ml}$ capacity glass, $80 \mathrm{ml}$ of water were added and the mixture was left for $20 \mathrm{~min}$. After the gelatin being swelled, $10 \mathrm{~g}$ of starch were added, the glass was put on the water bath and the liquor was heated at the temperature of $363 \mathrm{~K}$ during $40 \mathrm{~min}$. Then it was poured into a Petri dish, cooled to room (indoor) temperature and kept at $278 \mathrm{~K}$ during $3 \mathrm{~h}$; at $255 \mathrm{~K}$ during $24 \mathrm{~h}$. Thereafter the solution was defrosted and held indoor temperature to balance before the beginning of the experiments.

Preparation of starch cryotexturates. Starch cryotexturates were prepared by the following procedure: $10 \mathrm{~g}$ of starch were placed into the $300 \mathrm{ml}$ capacity glass, $90 \mathrm{ml}$ of water were added and the glass was put on the water bath and the liquor was heated at a temperature of $363 \mathrm{~K}$ during $40 \mathrm{~min}$. Then it was poured into a Petri dish, cooled indoor temperature and kept at $278 \mathrm{~K}$ during $3 \mathrm{~h}$; at $255 \mathrm{~K}$ during $24 \mathrm{~h}$. Then the solution was defrosted and held indoor temperature to balance before the beginning of the experiments.

The method of obtaining hydrophobic and hydrophilic jellies surfaces. The external surface of the jelly types (except cryotropic starch jelly), which are formed during solidification in a Petri dish on the verge air - solution, have a hydrophobic nature, which was confirmed by the value of contact angle wetting. At the same time, internal layers which were formed during solidification of the same jelly hydrophilic character and have the appropriate importance to this country it contact angle. Thus, the same type of jelly from the outside had a hydrophobic surface, and its internal layers are hydrophilic. To study the sorption properties of jellies a rectangular flat sample of the same size surface by weight of $2 \mathrm{~g}$ was cut.

Determination of sorption indexes of jellies. Wetting angles of jellies surfaces were studied by the method of drops spreading. Surface wetting angle with distilled water ( $\mathrm{pH}$ 5.5) was defined at $293 \mathrm{~K}$. A drop of water was dripped on the jellies surface and photographed through 1 min under macromode. In the picture obtained a tangent point which was on the interface of three phases was built and wetting angle was measured, as shown in Fig. 1. Depending on the severity of the angle we made the conclusion about hydrophobic or hydrophilic surface of jellies [13].

Thymol concentration was measured by photometric method [14] at the wavelength of $410 \mathrm{~nm}$.

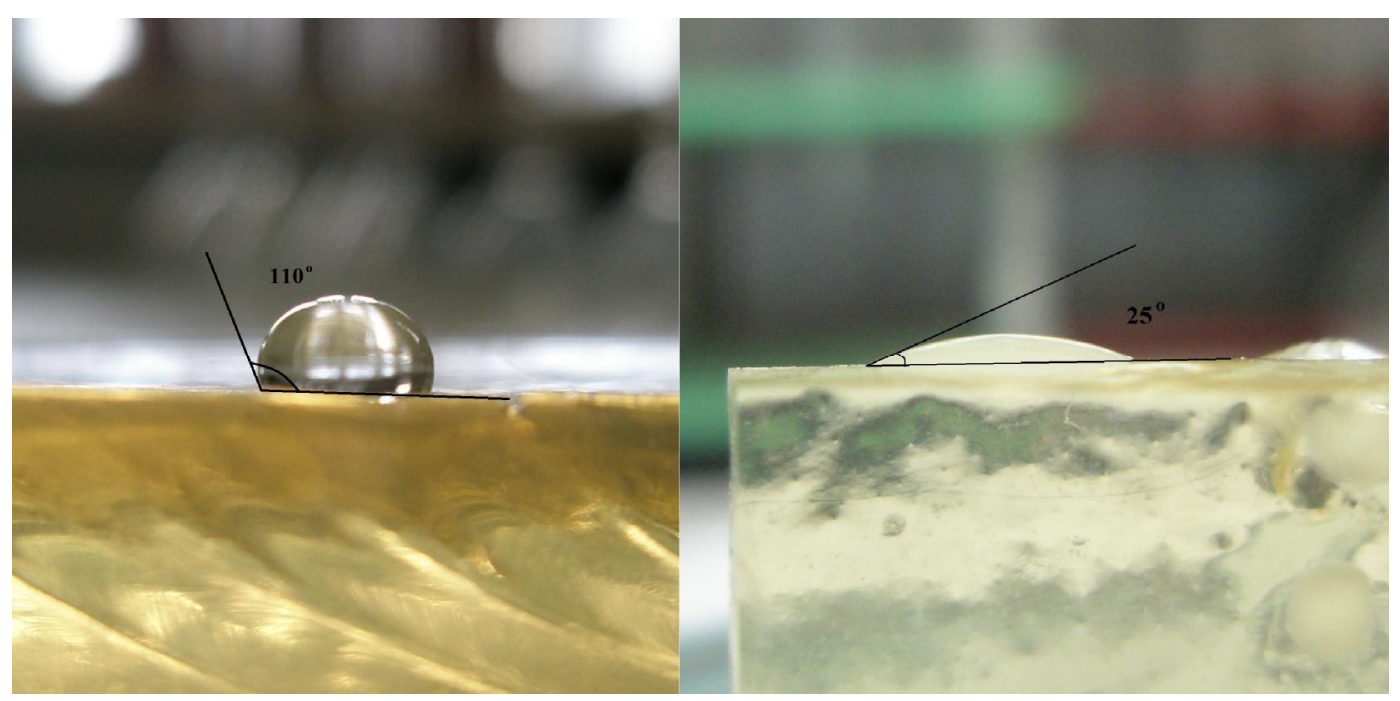

Fig. 1. Determination of contact wetting angle of jelly surfaces: surface, touched (a) and untouched (b) with air 
Thymol absorption of $0.1 \%$ aqueous solutions was carried out as follows: $50 \mathrm{ml}$ of $0.1 \%$ aqueous solution of thymol and $2 \mathrm{~g}$ of sorbent were stirred for $60 \mathrm{~min}$. Gel sample had a flat rectangle shape with the size of $1.0 \times 1.5 \times 1.3 \mathrm{~cm} .1 \mathrm{ml}$ of solution was selected and concentration of thymol was determined in it every $10 \mathrm{~min}$. Thymol adsorption from aqueous solutions is characterized by general binding $(R, \%)$ and distribution coefficient $(D)$, which are calculated in accordance with Eqs. (1) and (2):

$$
R=\frac{C_{0}-C}{C_{0}} \cdot 100 \%
$$

where $C_{0}$ - initial concentration of thymol solution, $\mathrm{mol} / \mathrm{l}$; $C$ - equilibrium concentration of thymol solution after definite time, $\mathrm{mol} / \mathrm{l}$.

$$
D=\frac{R}{100-R} \cdot \frac{V \cdot \rho}{m}
$$

where $V$ - volume of the sample solution, $\mathrm{ml} ; m$ - mass of the sorbent, $\mathrm{g} ; \rho$ - density of the solution $\mathrm{g} / \mathrm{ml}$.

The level of total binding is represented in Figs. 2 and 3 in the relative percentage $(R$, rel $\%)$. To do this, the least important overall indicator called "binding" $(R, \%)$ for a particular surface was taken as $100 \%$. For building sorption isotherms thymol concentration range of solutions with concentrations of $0.1,0.05,0.025,0.0125$, 0.00625 and $0.003125 \%$ was created. Then $1 \mathrm{~g}$ of the jelly was placed in flask and $25 \mathrm{ml}$ of a thymol concentration was added and the solution was stirred for 60 mins. Then $1 \mathrm{ml}$ of solution was taken and its concentration was determined.

To build sorption isotherms the sorption $(S)$ was calculated according to Eq. (3):

$$
S=\frac{C_{0}-C}{m} \cdot V
$$

where $C_{0}$ - initial concentration of thymol solution, $\mathrm{mol} / \mathrm{l}$; $C$ - concentration of the solution after the sorption of thymol, $\mathrm{mol} / \mathrm{l} ; V$ - volume of thymol solution taken for sorption, $1 ; m$ - mass of the sorbent, $\mathrm{g}$.

\section{Results and Discussion}

The results of the experimental determination of the contact angle of a jelly surface by method [13] are presented in Table 1.

Table 1

Contact angle of the gelatin, gelatin-starch and gelatin-thymol jellies surfaces and cryotexturates

$$
(P=0.95 ; n=3)
$$

\begin{tabular}{|c|c|c|}
\hline Jelly types & Jelly surfaces & Average value of an angle $\pm \varepsilon$ \\
\hline \multirow{2}{*}{ Thermotropic gelatin } & Hydrophobic & $109.7 \pm 3.8$ \\
\cline { 2 - 3 } & Hydrophilic & $30.7 \pm 5.2$ \\
\hline \multirow{2}{*}{ Thermotropic gelatin-starch } & Hydrophobic & $118.7 \pm 1.4$ \\
\cline { 2 - 3 } & Hydrophilic & $13.7 \pm 1.4$ \\
\hline \multirow{2}{*}{ Thermotropic gelatin-thymol } & Hydrophobic & $111.7 \pm 3.8$ \\
\cline { 2 - 3 } & Hydrophilic & $39.7 \pm 3.8$ \\
\hline \multirow{2}{*}{ Cryotropic gelatin } & Hydrophobic & $101.7 \pm 3.8$ \\
\hline \multirow{2}{*}{ Cryotropic gelatin-starch } & Hydrophilic & $52.0 \pm 2.5$ \\
\cline { 2 - 3 } & Hydrophobic & $121.0 \pm 4.3$ \\
\hline & Hydrophilic & $18.7 \pm 2.9$ \\
\hline
\end{tabular}

\begin{tabular}{|ll|}
\hline$\square$ Gelatin (eryotropic) & $\square$ Gelatin (thermotropic) \\
$\square$ Gelatin-starch (eryotropic) & $\square$ Gelatin-starch (thermotropic) \\
\hline
\end{tabular}

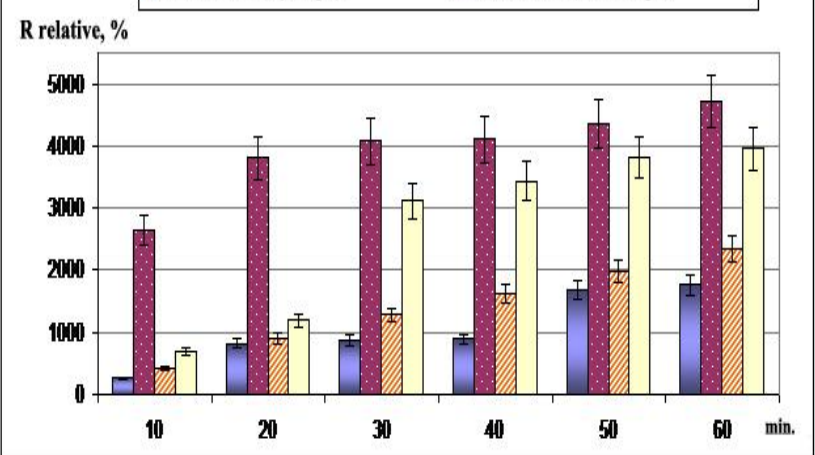

Fig. 2. Total binding of thymol by the hydrophobic surfaces of the thermo- and cryotropic jellies, depending on time

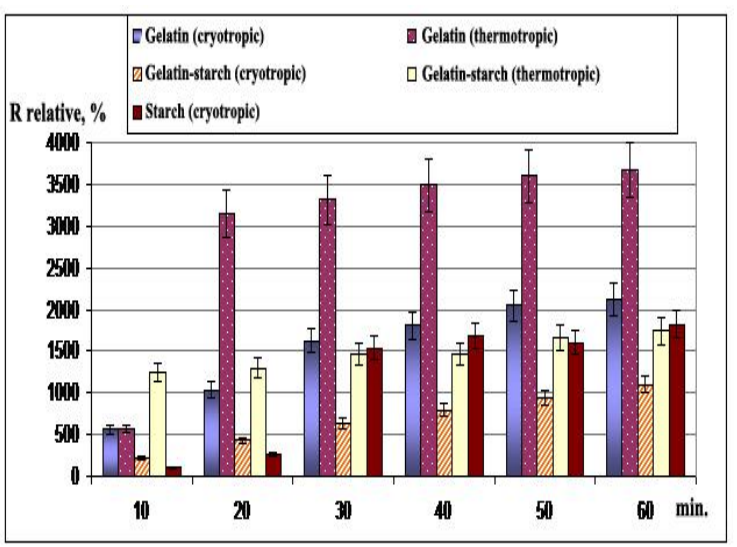

Fig. 3. Total binding of thymol by the hydrophilic surfaces of the thermo- and cryotropic jellies, depending on time 
Distribution coefficient of thymol on hydrophobic and hydrophilic surfaces of thermo- and cryotropic jellies depending on time $(P=0.95, n=3)$

\begin{tabular}{|c|c|c|c|c|c|}
\hline \multirow{4}{*}{$\begin{array}{l}\text { Sorption } \\
\text { duration, } \\
\text { min }\end{array}$} & \multirow{2}{*}{\multicolumn{5}{|c|}{$\begin{array}{c}\text { Distribution coefficient of thymol on hydrophobic surfaces of thermo- and cryotropic jellies depending on time } \\
\text { Distribution coefficient of thymol. } D\end{array}$}} \\
\hline & & & & & \\
\hline & \multicolumn{3}{|c|}{ Gelatin jellies } & \multicolumn{2}{|c|}{ Gelatin-starch jellies } \\
\hline & \multicolumn{2}{|c|}{ Thermotropic } & Cryotropic & Thermotropic & Cryotropic \\
\hline 10 & \multicolumn{2}{|l|}{$4.86 \pm 0.44$} & $0.41 \pm 0.04$ & $1.09 \pm 0.10$ & $0.68 \pm 0.06$ \\
\hline 20 & \multicolumn{2}{|l|}{$7.67 \pm 0.69$} & $1.34 \pm 0.12$ & $1.99 \pm 0.18$ & $1.46 \pm 0.13$ \\
\hline 30 & \multicolumn{2}{|l|}{$8.40 \pm 0.76$} & $1.42 \pm 0.13$ & $5.95 \pm 0.54$ & $2.14 \pm 0.19$ \\
\hline 40 & \multirow{2}{*}{\multicolumn{2}{|c|}{$\frac{8.48 \pm 0.77}{9.15 \pm 0.82}$}} & $1.46 \pm 0.13$ & \multirow{2}{*}{$\frac{6.72 \pm 0.60}{7.69 \pm 0.69}$} & $2.78 \pm 0.25$ \\
\hline 50 & & & $2.91 \pm 0.26$ & & $3.49 \pm 0.31$ \\
\hline 60 & \multicolumn{2}{|l|}{$10.22 \pm 0.93$} & $5 \pm 0.27$ & $8.06 \pm 0.73$ & $4.23 \pm 0.38$ \\
\hline \multicolumn{6}{|c|}{ Distribution coefficient of thymol on hydrophilic surfaces of thermo- and cryotropic jellies depending on time } \\
\hline \multirow{3}{*}{$\begin{array}{c}\text { Sorption } \\
\text { duration, } \\
\text { min }\end{array}$} & \multicolumn{5}{|c|}{ Distribution coefficient of thymol, $D$} \\
\hline & \multicolumn{2}{|c|}{ Gelatin jellies } & \multicolumn{2}{|c|}{ Gelatin-starch jellies } & Starch jellies \\
\hline & Thermotropic & Cryotropic & Thermotropic & Cryotropic & Cryotropic \\
\hline 10 & $0.90 \pm 0.08$ & $0.90 \pm 0.09$ & $2.07 \pm 0.19$ & $0.35 \pm 0.03$ & $0.16 \pm 0.02$ \\
\hline 20 & $6.01 \pm 0.54$ & $1.70 \pm 0.15$ & $2.18 \pm 0.20$ & $0.68 \pm 0.06$ & $0.41 \pm 0.04$ \\
\hline 30 & $6.43 \pm 0.58$ & $2.78 \pm 0.25$ & $2.47 \pm 0.22$ & $1.02 \pm 0.09$ & $2.62 \pm 0.24$ \\
\hline 40 & $6.85 \pm 0.62$ & $3.14 \pm 0.28$ & $2.47 \pm 0.21$ & $1.29 \pm 0.12$ & $2.89 \pm 0.26$ \\
\hline 50 & $7.13 \pm 0.64$ & $3.61 \pm 0.32$ & $2.85 \pm 0.26$ & $1.54 \pm 0.14$ & $2.74 \pm 0.25$ \\
\hline 60 & $7.33 \pm 0.66$ & $3.75 \pm 0.34$ & $3.00 \pm 0.28$ & $1.82 \pm 0.16$ & $3.16 \pm 0.28$ \\
\hline
\end{tabular}

According to the results of this research, all the surfaces of jellies formed during the contact with air (outward), are highly hydrophobic. Contact angle of the hydrophobic surface varied between $100^{\circ}$ and $123^{\circ}$. The surface of those jellies which were formed from a solution when frozen is hydrophilic in all cases. The surface of cryotropic starch jellies had the most hydrophilic nature: water is completely absorbed without forming a drop on the surface.

Experimental results that determine the total binding of thymol from aqueous solutions $(R, \%)$ and distribution coefficient $(D)$ depending on the time of sorption of thermotropic and cryotropic gels are shown in Figs. 2, 3 and Table 2.

According to the results, the increase in the amount of adsorbed thymol corresponds to the increase in contact time of the solution with the jellies. We observe the increased sorption activity of thymol on the hydrophobic surface after $60 \mathrm{~min}$ of the process beginning. This is especially true in case of thermotropic jellies. For example, total binding of the thermotropic gelatin jellies is 4700 rel \%, distribution coefficient -10.22 . At the same time the sorption of thymol in case of cryotropic gelatinstarch jellies was less active, total binding is $2300 \mathrm{rel} \%$, distribution coefficient -4.23 . In all cases, the adsorption equilibrium was established after $60 \mathrm{~min}$ of the process beginning and remained nearly constant for $24 \mathrm{~h}$.

The sorption ability of the hydrophilic surface of the jellies under study decreases in the following order: gelatin (thermotropic) > gelatin (cryotropic) > starch (cryotropic) > gelatin-starch (thermotropic) > gelatinstarch (cryotropic), thus remaining to be generally weaker compared with that of a hydrophobic surface. For example, after $60 \mathrm{~min}$ of sorption, the total binding by the hydrophilic surface of thermotropic gelatin jellies was 1.3 times lower compared to the hydrophobic surface, whereas the distribution coefficient was 1.4 times lower. The total binding by the hydrophilic surface of thermotropic gelatin-starch jellies was 1.9 times lower compared to the hydrophobic surface, whereas the distribution coefficient was 2.3 lower. The sorption of thymol by the hydrophilic surface of the cryotropic jellies of gelatin and starch reached its boundary value at the 60minute mark and remained nearly constant for $24 \mathrm{~h}$.

For the purpose of thermodynamic assessment of the sorption process of thymol from aqueous solutions by cryotropic jellies and thermotropic gelatin the sorption isotherms were constructed in the following coordinates: the concentration of adsorbed thymol $(G, \mathrm{~mol} / \mathrm{g}$ of sorbent) - concentration of thymol $(C, \mathrm{~mol} / \mathrm{l})$.

Comparison of sorption isotherms of thymol from aqueous solutions by the hydrophobic surfaces of the thermo- and cryotropic jellies is shown in Figs. 4 and 5.

The shape of isotherms depends on the degree of binding of thymol by the jellies. The isotherms for hydrophobic surfaces are S-shaped for all the jellies under study. Such shape indicates that the energy of interaction of the "adsorbent-adsorbate" model exceeds the interaction energy of the "adsorbate-adsorbate" model, meaning thymol has a high affinity to hydrophobic surfaces of the 
jellies. However, the sorption isotherms of thymol by the cryotropic gelatin and gelatin-starch gels have a significantly lower slope, indicating a decrease in the efficiency of sorption of thymol from aqueous solutions. This is especially true in case of cryotropic jellies. This is confirmed by the experimental results that determine the total binding of thymol. Thus, the total binding of cryotropic jellies by the hydrophobic surfaces is 2.7 times weaker on average compared to the thermotropic ones.

Comparison of sorption isotherms of thymol from aqueous solutions by the hydrophilic surfaces of the thermo- and cryotropic jellies is shown in Figs. 6 and 7.

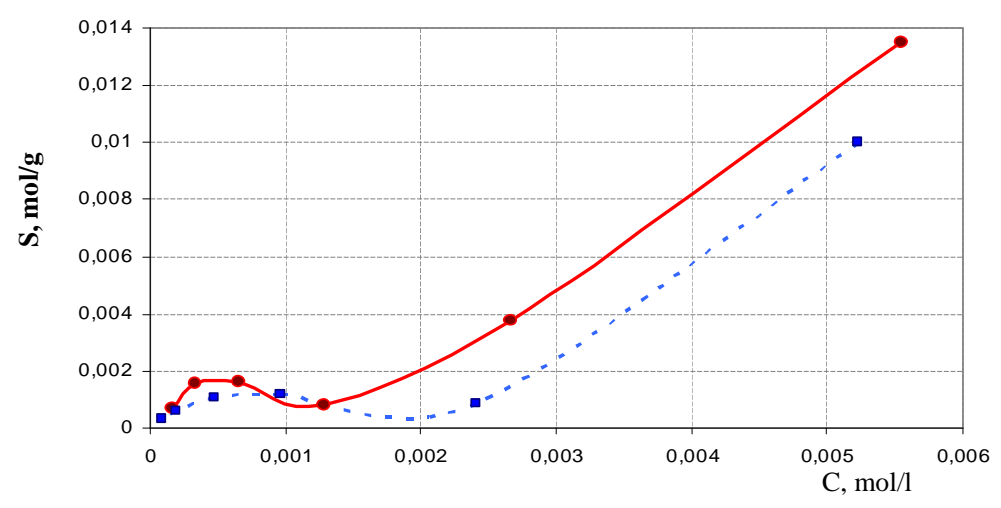

Fig. 4. The sorption isotherms of thymol by the hydrophobic surfaces of the $20 \%$ thermo- and cryotropic gelatin jellies: thermtropic $(\bullet)$ and cryotopic $(<)$

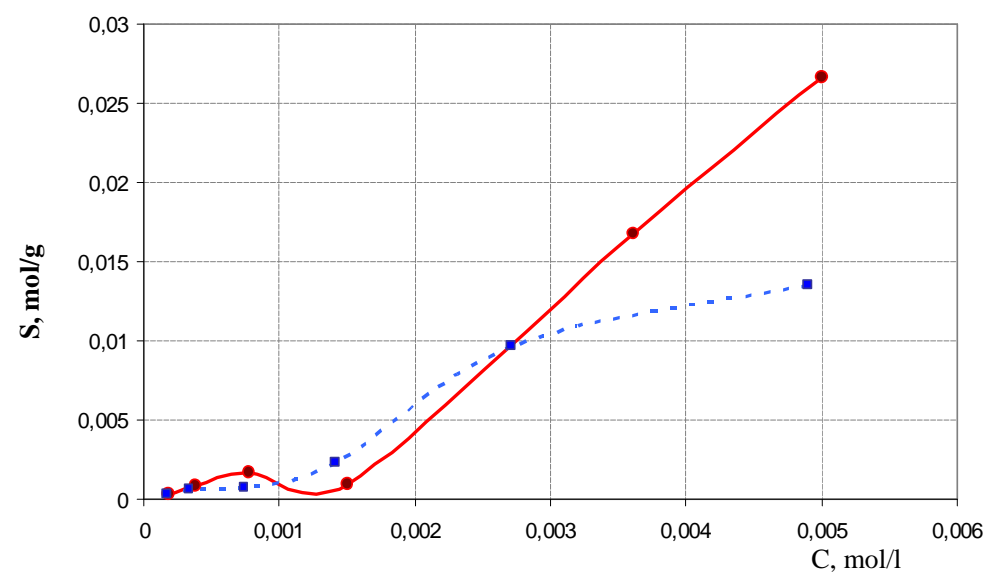

Fig. 5. The sorption isotherms of thymol by the hydrophobic surfaces of the thermoand cryotropic gelatin-starch jellies: thermtropic $(\bullet)$ and cryotopic $(<)$

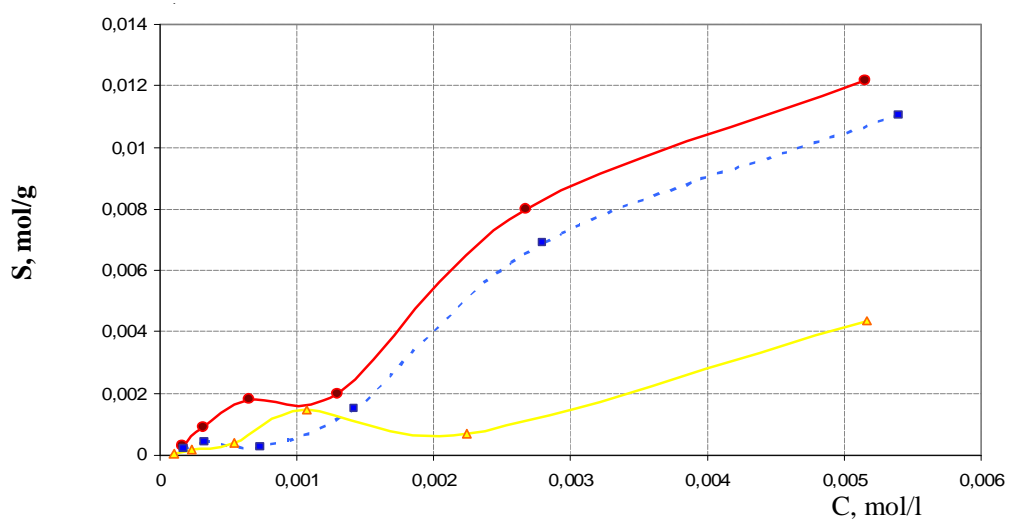

Fig. 6. Sorption isotherms of thymol by the hydrophilic surfaces of thermoand cryotropic jellies of gelatin and starch:

gelatin thermtropic $(\bullet)$, gelatin cryotopic $(<)$ and starch cryotropic $(\AA)$ 


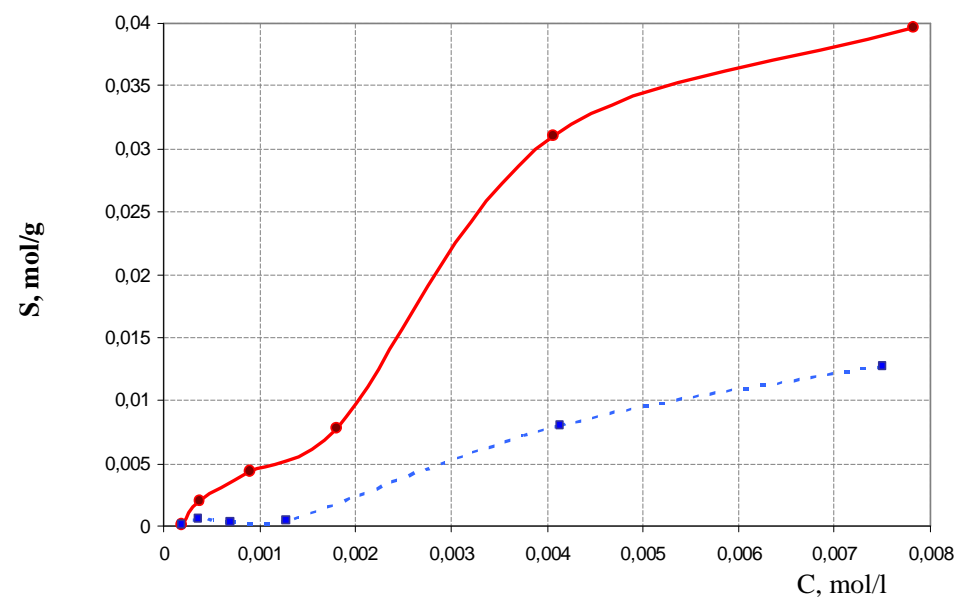

Fig. 7. Sorption isotherms of thymol by the hydrophilic surfaces of thermoand cryotropic gelatin-starch: thermtropic $(\bullet)$ and cryotopic $(<)$

In all cases, the isotherms are S-shaped, which indicates high affinity of thymol to adsorbents. However, there is a significant reduction in steepness of isotherms in a series of jellies: gelatin (thermotropic) > gelatin (cryotropic) > starch (cryotropic) > gelatin-starch (thermotropic), indicating a decrease in the efficiency of sorption. This is confirmed by the experimental data. For example, the level of total binding $(R$, rel \%) and distribution coefficient $(D)$ in the aforementioned series of jellies constitutes: $R=3700,2100,1700$ and 1100 rel \%; $\mathrm{D}=7.33,3.75,3.16$ and 3.00 , respectively.

In the course of our experiments, we found that in the concentration range none of the sorbents of thymol was able to reach the saturation stage (boundary value of the sorption).

The results suggest that weakly polarized benzoic ring of thymol is mainly adsorbed from solutions on hydrophobic surfaces of the thermotropic gelatin and gelatin-thymol jellies, which possess rigid enough spatial grid due to conformational transition of gelatin in the formation of jellies starting from a coil shape $(313 \mathrm{~K})$ and ending with a helix $(278 \mathrm{~K})$. Sorption in this case can only exist mainly because of hydrophobic interactions.

Introduction of thymol to the structure of the gelatin jellies, followed by its removal via desorption, did not lead to a significant increase in the total binding ability of thymol. Presumably, the gelatin-thymol jellies have bound a significant amount of thymol irreversibly, confirming experimental data. In this regard, thymol sorption from aqueous solutions has reached the boundary value of 900 rel \% $(D=7.45)$ for twenty minutes only in case of the gelatin-thymol jellies, but in other cases - it took $60 \mathrm{~min}$ for cryotropic jellies and $120 \mathrm{~min}$ for thermotropic ones to do the same.

Sorption of thymol on the hydrophobic surface of a sorbent takes place due to the hydrogen bonds between the hydroxyl group of thymol and hydroxyl groups of a sorbent (gelatin, starch). Irreversible sorption of thymol in this case increases up to $90 \%$. However, insufficient rates of this particular kind of sorption, in our opinion, can be explained by the competition of thymol with a large amount of water in jellies, which can also form hydrogen bonds with hydroxyl groups of starch and gelatin.

The fact that the additional noncovalent binding of molecules of biopolymers takes place inside the cryotropic jellies, which provides a rigid texture to a sponge, can indicate its higher sorption activity. However, according to the experimental data, a significant influence on the sorption in this case had a large amount of bound water in a cryotexturate, which competed with thymol. Overall, thymol sorption from water solutions on hydrophobic surface of both thermo- and cryotropic jellies is 2-2.5 times stronger compared to the hydrophilic one. Established sorption of thymol cryotropic jelly has more tightly fixed conformation than thermotropic jelly. Thus, the sorption of thymol by the thermo- and cryotropic jellies of gelatin and starch is caused mainly by the formation of hydrophobic bonds between thymol and sorbent. The degree of binding of thymol with sorbents was decreasing in case of cryotropic jellies because of the presence of a large amount of bound water that can form hydrogen bonds with hydroxyl groups of biopolymers.

\section{Conclusions}

It is shown that jelly surface formed on the edge of solution-air is hydrophobic with the wetting angle of $101.7-121.0^{\circ}$ and jellies surface formed in solution, from the inner layers (internal volume) of gels, is hydrophilic with the boundary wetting angle of $13.7-52.0^{\circ}$. Impact surface of hydrophobic jellies investigated for their ability 
to absorb thymol from aqueous solutions was confirmed. It was confirmed that the most promising technology of creating flavors from aromatic substances are thermotropic jellies and gelatin with hydrophobic surface.

\section{References}

[1] Andrienko V.: Pishhevaya Prom., 2001, 10, 63.

[2] Golovnya R., Misharina T.: Izvest. Akad. Nauk. Seriya Khim., 1998, 2, 310.

[3] Krikunova N., Terenina M., Ruchkina E., Misharina T.: Appl. Biochem. Microbiol., 2006, 42, 379. https://doi.org/10.1134/S0003683806030203

[4] Misharina T., Mukhutdinova S., Zharikova G. et al.: Appl. Biochem. Microbiol., 2009, 45, 207.

https://doi.org/10.1134/S0003683809020124

[5] Terenina M., Misharina T.: Appl. Biochem. Microbiol., 2005, 41, 463.

[6] Fares K., Landy P., Guilard R., Voilley A.: J. Dairy Sci., 1998, 81, 82. https://doi.org/10.3168/jds.S0022-0302(98)75554-7

[7] Miller K., Upadhyaya S., Krochta J.: J. Food Sci.,1998, 63, 244. https://doi.org/10.1111/j.1365-2621.1998.tb15718.x

[8] Misharina T., Terenina M., Krikunova N., Medvedeva I.: Appl. Biochem. Microbiol., 2016, 52, 226.

https://doi.org/10.1134/S0003683816020113

[9] Lashko N., Krasna T.: Visnyk Zapor. Nats. Univ., 2015, 2, 218. [10] Lashko N. Egorova Yu.: Visnyk Zapor. Nats. Univ., 2013, 1, 129.
[11] Savary G., Hucher N., Petibon O., Grisel M.: Food Hydrocolloids, 2014, 37, 1.

https://doi.org/10.1016/j.foodhyd.2013.10.026

[12] Samavati V., Emam-Djomeh Z., Mehdinia A., Mohammadifar M.: Iran. J. Chem. Chem. Eng., 2012, 31, 85.

[13] Morrison S.: The chemical physics of a solid surface, Mir, Moskva 1980.

[14] Korenman I.: Fotometricheskiy Analiz. Metody Opredeleniya Organicheskikh Soedineniy. Khimiya, Moskva 1975.

Received: January 10, 2017 / Revised: M arch 03, 2017 / Accepted: M ay 31, 2017

\section{ЗВ'ЯЗУВАННЯ АРОМАТОУТВОРЮЮЧИХ РЕЧОВИН КРІО- ТА ТЕРМОТРОПНИМИ ДРАГЛЯМИ ЖЕЛАТИНИ І КРОХМАЛЮ}

Анотація. Вивчені закономірності зв'язування ароматоутворюючих речовин кріо- та термотропними драглями желатини і крохмалю. Експериментально підтверджено вплив гідрофобної поверхні досліджуваних драглів на їх здатність сорбувати тимол із водних розчинів. Встановлено зменшення сорбиї тимолу кріотропними драглями порівняно з термотропними. Експериментально підтверджено, щуо технологічно найбільш перспективним для створення ароматизаторів на основі гідрофобних ароматичних речовин $\epsilon$ термотропні драглі желатини з високою гідрофобністю.

Ключові слова: тимол, желатина, крохмаль, гідрофобність, гідрофільність, кут змочування, сорбиія, десорбиія. 